\title{
PROBLEMS WRITING FROM DICTATION FOR BLIND AND VISUALLY IMPAIRED STUDENTS
}

\section{Ševala Tulumović ${ }^{1}$ \\ Branka Eškirović \\ Izeta Husić-Đuzić}

Faculty of Education and Rehabilitation, University of Tuzla

Faculty of Special Education and Rehabilitation, University of Belgrade

Elementary school "Mejdan", Tuzla

Received: 18.12.2016

Accepted: 23.01.2017

\author{
Original scientific paper
}

DOI: $10.21554 / \mathrm{hrr} .041704$

\begin{abstract}
Aim of this research was to get insight into mistakes that occur while blind and visually impaired students, and students with no visual disabilities, when writing by dictation. Respondents sample was consisted of three groups of students: blind $(N=51)$, visually impaired $(N=42)$ and students with no visual disabilities $(N=123)$. Respondents sample included students from first to fourth grade of elementary schools in Tuzla Canton as well as blind and visually impaired students from boarding schools and students from first to fifth grade in centers for blind and visually impaired children and youth, as well as population of blind and visually impaired students from first to fourth grade that are integrated into regular elementary schools in Tuzla Canton in Bosnia and Herzegovina. Obtained results have shown that in variable groups for errors estimate in variables for writing by diction of words consisting of uppercase and lowercase letters, where blind and visually impaired students mostly made mistakes in form of inability to write dictated words, grammatical errors, errors in letters and syllables: relocation, leaving out, adding, separating words and concatenating them. Level of literal development is very important for preventive acting as well as timely rehabilitation.
\end{abstract}

Keywords: Visually impaired students, Students with no visual disabilities, writing by dictation

\section{INTRODUCTION}

School has always been one of the mayor roads to education. Today's society requests from schools to make every single individual get out of the mass to the level he belongs to, this means to take advantage of their natural abilities and the benefits of society in order to contribute to the society for his own and the benefit of community (Stevanovic, 2000). Modern views on student's learning in the process of organizing classes are for student to explore by learning and learn by exploring (Klafki, 1992). Listening cannot completely replace written word which implicates the need for children with visual disabilities to write. Tactile as well as visual are rarely confronted with written word and text, which has as a consequence slower writing, insufficient or event poor spelling and grammar knowledge, they are uncertain about lexicon, poor expression (especially in written form) (Tulumovic, 2013). Some studies claim that persons with early amaurosis can have very good tactile abilities (Dangiulli \& Waraich, 2002). It is often forgotten that perception of visually impaired students is incomplete, impoverished and often fragmentized. Visually impaired students are not as transparent as blind students about their disabilities, which results in misunderstandings and wrong approaches.

\footnotetext{
${ }^{1}$ Correspondence to:

Ševala Tulumović, Faculty of Education and Rehabilitation, University of Tuzla

Univerzitetska 1, 75000 Tuzla, B\&H

Phone: 0038761641341

E-mail: sevala.tulumovic@untz.ba
} 
Experience has shown that visually impaired students have more difficulties in learning at school than blind students (Matok, 2006). Visual impairment has influence on the state of graph-motor abilities of students affected by it. When accomplishing the act of writing, hand must be able to grab precisely, it has to take specific position and utilize certain amount of power through certain amount of time (Tulumovic, 2009). Most common causes of difficulties in reading and writing abilities of students with visual impairments are: spatial orientation disorder, letter or words writing disorder, visual perception disorder, additive perception and discrimination disorder, lack of visual memory etc. (Vladisavljevic, 1984). Extremely visual perceptual and graph-motor disabilities of children with visual impairment require special attention in differential - diagnostic and rehabilitation approach with visual and motor difficulties in writing (Tulumovic, 2013).

Orthography in Bosnian language doesn't just mean spelling and orthographic norm of writing (usage of lowercase and uppercase letters, separating words at the end of the row, writing foreign names etc.), it also means grammatical and vocal norm and in a broader sense than orthographic norm requires (Gavran, 2007). Argyropoulos and Martos (2006) conducted an analysis of grammatical and orthographic errors on 16 blind students. Results have shown a lot of particularities in form of grammatical and orthographic mistakes, attitude of students towards orthography and relations between orthography and reading strategies. Manuscript of students with visual impairments is very specific and mostly graphical shaping of letters and tidiness are not as good as those of children with not visual impairments (Matok, 2006). Children have to go through systematic exercises that contain all elements of reading and writing. Every element of learning letters have to be dealt with care, and those elements are: letter recognition through analysis and synthesis of speech, letter recognition in isolation and in context, preparation of graph-motor exercise and writing graphemes (Farago, 1996). The whole process of teaching students with visual impairments is a relative factor and two different groups of students can have different visual impairments, so that literature for every child should be appropriate to its individual problems (Craig, DePriest \& Harnack, 1997). The process of teaching of children with impaired vision was examined in this study, where the competence of teachers, usage of educational media and the way of assessment was studied. The results showed a statistically significant difference between the assessment, teacher competence and use of educational media (DeMario \& Lian, 2000). Vik and Fellenius came to similar results as in this study conducted on students with impaired vision, (2007) who point out that educational media for writing and transcription by visually impaired students should be appropriate and in accordance with their individual needs (Braille, black print, auditory material, etc.), in order to educate students undisturbed in schools. Dictates fall into semiwritten work, where the teacher dictates certain content to students, and the students shape it by writing (Vilotijević, 1999). Bonoti, Vlachos and Metallidou (2005) conducted a study whose aim was to investigate a possible link between writing, transcribing and writing from dictation and drawing skills of students of school age in comparison with other skills within their individual levels (direction, position, left-handed, right-handed, etc.). The sample consisted of 182 students aged from 8 to 12 years. Spontaneously writing, transcribing and writing from dictation of students was tested with four different tasks of drawing. The results showed a significant correlation between the success of drawing and the results obtained in all three tasks of written expression. There was no significant difference in skills between left-handed and right-handed students. Students with lower scores in the written language have greater difficulty in continuing education, and therefore special attention should be given to the written language (Farago, 1996). A huge role in the success of writing of students with visual impairments have perceptual factors, intellectual development, teaching methods, etc. (Orlansky, 1981). In writing braille grapheme most common mistakes are incorrectly written letters, and that this error occurs in all projections of letters. The reason for this is due to under-built and fixed relief form of letters, as well as the lack of mechanized movement of fingers, and writing using Braille machine (Cvetković, 1989). The most common error in second grade students is uppercaseization of letters, punctuation and grammar (Duranović, 2006). Under the skill of writing, writing complete sentences, proper use of spelling and grammar rules in accordance with the child's age, is understood. Children with lower scores in the written language have greater difficulty in continuing education, and therefore special attention should be given to the written part of language (Tulumović, Adilović \& Hadžić, 2012). 


\section{OBJECTIVE}

To examine the difference in making mistakes when writing a word by the dictates of uppercase and lowercase letters between students with and without visual impairment.

\section{METHODS}

\section{Sample of respondents}

The sample consists of three groups of students: blind, visually impaired and students without visual impairment, obtained from a population of students from first to fourth grade of primary schools in Tuzla Canton and the population of blind and visually impaired students residential accommodation also from first to fourth grade at the Centre for Blind and Visually Impaired Children and Youth, as well as the population of blind and visually impaired students from first to fourth grade who are integrated into regular primary schools in Tuzla Canton.

\section{Sample of variables}

A total of 16 variables were analyzed

RIJV_NRI_D-inability of writing words in uppercase letters when writing from dictation; RIJV_GRI_Derror at the level of words (decomposed writing of parts of the same word, morphologic disgramatism); RIJV_GSS_D- errors at the level of letters and syllables (moving, omission, addition, no correspondence) when writing the words in uppercase letters from dictation;

RIJV_PRG_D- spelling mistakes when writing a word in uppercase letters from dictation; RIJV FFG D- phonological and phonemic errors when writing the words in uppercase letters from dictation; RIJV_KNG_D-kinetic mistakes when writing a word in uppercase letters from dictation; RIJV_OPG_Doptical errors when writing the words in uppercase letters from dictation; RIJV_ISP_D- properly writing of words in uppercase letters when writing from dictation; RIJM_NRI_D- inability of writing words in lowercase letters when writing from dictation; RIJM_GRI_D- error at the level of words (decomposed writing of parts of the same word, morphologic disgramatism), while writing words in lowercase letters from dictation; RIJM_GSS_D- errors at the level of letters and syllables (moving, omission, addition, no correspondence) when writing the words in lowercase letters from dictation; RIJM_PRG_Dspelling mistakes when writing words in lowercase letters from dictation; RIJM_FFG_D- phonological and phonemic errors when writing words in lowercase letters from dictation; RIJM_KNG_D- kinetic mistakes when writing a word in lowercase letters from dictation; RIJM_OPG_D- optical errors when writing the words in lowercase letters from dictation; RIJM_ISP_D- properly writing of words in lowercase letters when writing from dictation.

\section{Method of conducting research and measuring in- struments}

To test writing words with upper and lower case letters by dictate, the "Diagnostic kit for testing of speech, language, reading and writing of children" was used (Bjelica and Posokhova, 2001.). Dictate of words was conducted so that a dictate to the child was held, and the child wrote it down. Writing down words with upper and lower case letters by dictate had the goal to examine the acquisition connection "speech-letter". The testing was conducted by the examiner dictating words to the child in upper and lower case, and the child wrote them down. Evaluation of writing skills by dictating words in upper and lower case was conducted qualitatively. The analysis determined the number of errors for each subject, and because of the specificity of the population that was examined (blind and visually impaired students) testing was done individually.

\section{Methods of data processing}

The obtained data was statistically analyzed using the computer program SPSS 10.0 for Windows. In order to determine the difference in the number of errors calculated by the chi-square test. All studies were performed with a significance level of $5 \%$ (0.05).

\section{RESULTS}

The results showed that the three groups of subjects differ by the examined variable of writing words in uppercase letters. They showed that blind students in $19.61 \%$ of cases are not able to write words in uppercase letters by dictate, and the visually impaired in $9.52 \%$ of cases. 
Blind students make grammatical errors when writing by dictate in $35.29 \%$ of cases, and visually impaired students less frequently than blind students, but still very frequently $21.43 \%$. However the results of number of errors at the level of letters and syllables (moving, omission, adding letters, forgetting letters) students with im- paired vision had a greater number of errors, even $61.90 \%$. Blind students had this kind of mistakes at a frequency of $43.14 \%$. Approximately the same number of spelling errors had impaired and blind students. The feature of correct spelling of words by dictate did not have $48.78 \%$ of students without impairment.

Table 1.Differences in variables when writing by dictate of students with and without visual impairment

\begin{tabular}{lcccc}
\hline DKRIVSL & $\begin{array}{c}\text { Students without } \\
\text { impairment }\end{array}$ & $\begin{array}{c}\text { Students with } \\
\text { visual } \\
\text { impairments }\end{array}$ & Blind students & Chi-square \\
\hline RIJV_NRI_D & $0.00 \%$ & $9.52 \%$ & $19.61 \%$ & $\mathbf{2 2 . 1 3}$ \\
RIJV_GRI_D & $0.00 \%$ & $21.43 \%$ & $35.29 \%$ & $\mathbf{3 9 . 2 5}$ \\
RIJV_GSS_D & $0.00 \%$ & $61.90 \%$ & $43.14 \%$ & $\mathbf{6 7 . 1 3}$ \\
RIJV_PRG_D & $0.00 \%$ & $2.38 \%$ & $1.96 \%$ & $\mathbf{2 . 6 9}$ \\
RIJV_FFG_D & $2.44 \%$ & $4.76 \%$ & $0.00 \%$ & $\mathbf{2 . 2 8}$ \\
RIJV_KNG_D & $7.32 \%$ & $0.00 \%$ & $0.00 \%$ & $\mathbf{6 . 8 0}$ \\
RIJV_OPG_D & $39.02 \%$ & $0.00 \%$ & $0.00 \%$ & $\mathbf{3 6 . 2 9}$ \\
RIJV_ISP_D & $51.22 \%$ & $0.00 \%$ & $0.00 \%$ & $\mathbf{4 7 . 6 3}$ \\
& $\mathbf{1 0 0 . 0 0 \%}$ & $\mathbf{1 0 0 . 0 0 \%}$ & $\mathbf{1 0 0 . 0 0 \%}$ & \\
\hline
\end{tabular}

When writing by dictate words in lower case we can also conclude that the studied groups differ. A slightly larger number of errors at the level of words (decomposed writing of parts of the same word, joined writing of parts of different words) had blind students, even $35.29 \%$, and visually impaired students $16.67 \%$.
Visual impaired students had a greater number of errors at the level of letters and syllables, $57.14 \%$, than blind students, $43.14 \%$. The feature of correct spelling of lowercase by dictate had $51.22 \%$ students without visual impairment. This feature was not present in students with visual impairments.

Table 2. Differences in variables when writing by dictate of students with and without visual impairment

\begin{tabular}{lcccc}
\hline DIKRIMSL & $\begin{array}{c}\text { Students without } \\
\text { impairment }\end{array}$ & $\begin{array}{c}\text { Students with visual } \\
\text { impairments }\end{array}$ & Blind students & Chi-square \\
\hline RIJM_NRI_D & $13.82 \%$ & $19.05 \%$ & $19.61 \%$ & $\mathbf{1 . 0 1}$ \\
RIJM_GRI_D & $0.00 \%$ & $16.67 \%$ & $35.29 \%$ & $\mathbf{3 9 . 9 7}$ \\
RIJM_GSS_D & $0.00 \%$ & $57.14 \%$ & $43.14 \%$ & $\mathbf{6 2 . 9 6}$ \\
RIJM_PRG_D & $0.00 \%$ & $2.38 \%$ & $1.96 \%$ & $\mathbf{2 . 6 9}$ \\
RIJM_FFG_D & $2.44 \%$ & $4.76 \%$ & $0.00 \%$ & $\mathbf{2 . 2 8}$ \\
RIJM_KNG_D & $4.88 \%$ & $0.00 \%$ & $0.00 \%$ & $\mathbf{4 . 5 4}$ \\
RIJM_OPG_D & $30.08 \%$ & $0.00 \%$ & $0.00 \%$ & $\mathbf{2 7 . 9 8}$ \\
RIJM_ISP_D & $48.78 \%$ & $0.00 \%$ & $0.00 \%$ & $\mathbf{4 5 . 3 7}$ \\
& $\mathbf{1 0 0 . 0 0 \%}$ & $\mathbf{1 0 0 . 0 0 \%}$ & $\mathbf{1 0 0 . 0 0 \%}$ & \\
\hline
\end{tabular}




\section{DISCUSSION}

Based on the results we can conclude the importance of timely education and rehabilitation for a successful education process of blind and visually impaired students, those are appropriate to their specific needs and abilities. Students with lower scores in the written language have greater difficulty in continuing education. Usage of spelling and punctuation in writing gives a written speech a thoughtful content and the beauty of written expression. A major impact on the success in writing has age, or chronological age of the child (Vlachos \& Bonoti, 2004.). Eškirović, Jablan and Vučinić (2005) came to the finding that children with low visual acuity on proximity, certainly have problems with writing letters of more complex graphical structures or their proper connectivity. When it comes to writing, an inadequate linking of words and failure to realize the relationship of letters and words in a sentence occurs. Inability of having a complete visual perception and orientation manifests in interference and distortion of letters. Difficulties in writing arise as a result of difficulties in the realization of graphomotoric acts and graphic symbolization of units of speech, so that children cannot get to the end to shape letters and words so they move them because of their inability to organize their harmonious form and sequence (Veljković, 2003). Dikić (1991) has examined the correlation of errors or difficulty in writing and visual impairment in a sample of 43 visually impaired students, who have different forms and degrees of visual impairment. The research revealed that only $23.25 \%$ of respondents had graphomotoric interference, $46.57 \%$ had significant difficulties, and $30.23 \%$ had disturbances expressed in milder form. Dikić, Eškirović and Strahinjević carried out the assessment of the maturity of the manuscript on a sample of 50 visually impaired children, older school age, using the "Scales for assessing the maturity of handwriting" by Ažiriagera, Ozias. The results showed that, in terms of maturity of manuscripts, $52 \%$ of them are one or more years behind the levels of their age, $32 \%$ is at the level of their age, and $16 \%$ are above the level of their age. There was a positive correlation between the maturity of handwriting and visual impairment as a cause of visual impairment, visual acuity, level of intelligence, age and school success. Very low results in terms of maturity of handwriting, achieved visually impaired students with changes in the optic nerve. It is en- couraging; however, that maturity of the manuscript visually impaired children increase with increasing of their age (Eškirović, 2002). Golubovic (2000) points out that child with underdeveloped auditory perception cannot accurately perceive the word as a whole, divided them into their constituent parts, or translate voices into letters, which is necessary for proper writing. Therefore, children while writing by dictate replace, omit letters syllables and words. Difficulties in writing arise due to discord in the organization of melokinetic and constructive praxis. This is a development issue outside the practices that may occur due to poor graphic enforcement of the act of writing (Ćordić \& Bojanin, 1992). For people with visual impairments literacy is imperative for achieving social equality and emancipation of their merits and abilities. This is, therefore, their basic need and a right to the educational process, which is guaranteed to them by law on education in almost all countries of the modern world. Visual impairment is therefore not the way to marginalization but illiteracy certainly is. Education that does not meet the specific needs of children with visual impairments in writing may have significant negative implications for the balance of their perceptual, graphomotoric and cognitive abilities. Prominent visual-perceptual and graphomotor difficulties of children with visual impairments require special attention in the differential-diagnostic and rehabilitative approach to the skills and abilities.

\section{CONCLUSION}

Based on the knowledge acquired during the development this work, as well as on the basis of the results of the research it can be concluded that, when writing words in upper and lower case by dictate blind and visually impaired students mostly made mistakes in the form of inability to write dictated words, making grammatical errors, errors at the level of letters and syllables in terms of relocating, omissions, additions, forgetting letters, decomposed writing of parts of the same word, decomposed writing of parts of the same word, that visually impaired students were much weaker. We can see that blind children and visual impaired children because of the complete absence or reduced visual perception have no basis for a visual representation of the environment by which they are largely limited in terms of written expression in relation to their peers with intact vision. 


\section{REFERENCES}

Argyropoulos, V.S., Martos, A.C. (2006). Braille literaci skills: An analysis of the concept of spelling. Journal of Visual Impairment \& Blindness 100 (11): 676-686.

Bonoti, F., Vlachos, F., Metallidou, P. (2005). Writing and drawing performance of school age children is there any relationship. School Psychology International 26 (2): 243-255.

Bjelica, J., Posokhova, I. (2001). Dijagnostički komplet za ispitivanje sposobnosti govora, jezika, čitanja i pisanja djece. Lekenik: Ostvarenje.

Craig, C.J., DePriest, L., Harnack, K. (1997). Teachers perspectives on selecting literacy media for children with visual impairments. Journal of Visual Impairment \& Blindness 91 (6): 539-545.

Cvetković, Ž. (1989). Metodika vaspitno-obrazovnog rada sa slijepim licima. Beograd: Defektološki fakultet Univerziteta u Beogradu.

Ćordić, A., Bojanin, S. (1992). Opšta defektološka dijagnostika. Beograd: Zavod za udžbenike i nastavna sredstva.

Dangiulli, A., Waraich, P. (2002). Enhanced tactile encoding and memory recognition in congenital blindnes. International Journal of Rehabilitation Research 25 (2):143145.

DeMario, N.C., Lian, M.G.J. (2000). Teachers perceptions of need for and competency in transcribing Braille materials in the Nemeth code. Journal of Visual Impairment \& Blindness 94 (1): 7-14.

Duranović, M. (2006). Procjena fonoloških i semantičkih sposobnosti kod djece sa disleksijom i disgrafijom. Doktorska disertacija. Edukacijsko-rehabilitacijski fakultet Univerziteta u Tuzli.

Dikić, S. (1991). Metodika vaspitno-obrazovnog rada sa slabovidim učenicima. Beograd: Naučna knjiga.

Eškirović, B. (2002). Vizualna efkasnost slabovide dece u nastavi. Beograd: SD Publik.

Eškirović, B., Jablan, B., Vučinić, V. (2005). Smetnje $i$ poremećaji u razvoju kod dece oštećenog vida U: Golubović i saradnici. Smetnje i poremećaji kod dece ometene u razvoju. Beograd: Defektološki fakultet, 225-239.
Farago, E. (1996). Strukture procesa pisanja u djece s teškoćama u čitanju i pisanju. Doktorska disertacija. Fakultet za defektologiju Sveučilišta u Zagrebu.

Golubović, S. (2000). Disleksija. Beograd: Univerzitetska štampa.

Gavran, M. (2007). Mali razredni list u funkciji ostvarivanja nekih općih ciljeva razvoja pismenosti. Dolinapožeškoslavonski obrazovni portal http://www.dolina. $\mathrm{hr} /$ članak.asp?id.

Klafki, W. (1992). Didaktičke teorije. Zagreb: Educa.

Matok, D. (2006). Integracija učenika s oštećenjem vida. Hrvatski savez slijepih. http://www.savez-slijepih.hr/hr/ stručniradovi/referati/vid/index.htm.

Orlansky, M.D., Rhyne, J.M. (1981). Special adaptations necessitated by visual impairments u: Kauffman JM, Hallahan DP, Hanbook of special eduaktion, Prentice-Hall, Inc, Englewood Cliffs.

Stevanović, M. (2000). Modeli kreativne nastave. Tuzla: DOO „GRAFIČAR“.

Tulumović, Š. (2013). Usmena i pismena komunikacija djece $s$ oštećenjem vida, OFF SET, Tuzla.

Tulumović, Š., Adilović, Dž., Hadžić, S. (2012). Pisanje po diktatu učenika sa i bez oštećenja vida. Defektologija, 18 (2): 112-115.

Tulumović, Š. (2009). Greške prilikom prepisivanja teksta kod slijepih, slabovidnih i učenika bez oštećenja vida. Didaktički putokazi, časopis za nastavnu teoriju i praksu (53): 2-5.

Vik, A.K., Fellenius, K. (2007). Coping strategies in reading: Multi-readers in Norwegian general education system. Journal of Visual Impairment \& Blindnes 101 (9): 545556.

Vlachos, F., Bonoti, F. (2004). Handedness and writing performance. Perceptual and motor skills 98 (3): 815-824.

Vilotijević, M. (1999). Didaktika. Beograd: Naučna knjiga i Učiteljski fakultet.

Vladisavljević, S. (1984). Poremećaji čitanja i pisanja. Beograd: Zavod za udžbenike i nastavna sredstva SR Srbije.

Veljković, V. (2003). Teškoće u čitanju i pisanju. Priručnik za inkluzivnu nastavu, Humanitarna organizacija Duga, 44-9. 